\title{
Primary spinal primitive neuroectodermal tumour: report of two cases mimicking neurofibroma and review of the literature
}

\section{Pierwotny prymitywny guz neuroektodermalny kanału kręgowego naśladujacy nerwiakowłókniaka - opis dwóch przypadków i przegląd piśmiennictwa}

Ashis Patnaik, Sudhansu Mishra, Sanjib Mishra, Rama Deo

SCB Medical College, Cuttack, India

Neurologia i Neurochirurgia Polska 2012; 46, 5: 480-488

DOI: 10.5114/ninp.2012.31360

\begin{abstract}
Primary spinal primitive neuroectodermal tumours (PNETs) are a rare entity. Most of them occur in children and young adults. To date, 47 cases of primary spinal PNET have been reported in the literature. We present two cases of primary spinal PNET. In both cases, the tumours were thoracic extradural ones with intrathoracic extension through intervertebral foramina resembling neurofibroma. These tumours are highly aggressive with rapid growth as evidenced by the short history in both of our cases. Both cases underwent gross total removal of the intraspinal and thoracic components. Postoperatively, both patients underwent cranio-spinal radiotherapy.

A review of the literature shows that the overall prognosis of PNETs of the spinal cord is very poor even with adequate surgery, radiotherapy and chemotherapy. One patient died after 4 months and the other one is still alive 8 months after surgery, radiotherapy and chemotherapy.
\end{abstract}

Key words: primitive neuroectodermal tumour, primary, spinal, neurofibroma.

\section{Streszczenie}

Prymitywne guzy neuroektodermalne (primitive neuroectodermal tumours - PNET) umiejscowione pierwotnie w kanale kręgowym należą do rzadkości. Większość z nich występuje u dzieci lub młodych osób dorosłych. Do tej pory opisano 47 przypadków PNET w tej lokalizacji. W niniejszej pracy prezentujemy dwa takie przypadki. U obu chorych guzy były umiejscowione zewnątrztwardówkowo w odcinku piersiowym kanału kręgowego i szerzyły się poprzez otwory międzykręgowe do wnętrza klatki piersiowej w sposób przypominający nerwiakowłókniaka. Opisywane guzy mają bardzo agresywny przebieg i rosną szybko, na co wskazuje krótki wywiad w obu opisywanych przypadkach. Obie pacjentki poddano makroskopowo doszczętnemu wycięciu wewnątrzkanałowej i znajdującej się we wnętrzu klatki piersiowej części guza. Po operacji obie chore poddano radioterapii czaszki i kanału kręgowego.

Przegląd piśmiennictwa wskazuje, że ogólne rokowanie w PNET rdzenia kręgowego jest złe nawet mimo właściwego leczenia chirurgicznego połączonego $\mathrm{z}$ radio- $\mathrm{i}$ chemioterapią. Jedna z opisywanych pacjentek zmarła po 4 miesiącach od operacji, druga przeżyła dotąd 8 miesięcy po leczeniu chirurgicznym, radio- $\mathrm{i}$ chemioterapii.

Słowa kluczowe: prymitywny guz neuroektodermalny, pierwotny, rdzeniowy, nerwiakowłókniak.

Correspondence address: Mch, Ashis Patnaik, SCB Medical College, Manglabag 753007, Cuttack, India, e-mail: dr ash@yahoo.co.in Received: 5.12.2011; accepted: 25.01.2012 


\section{Introduction}

The term 'primitive neuroectodermal tumour' (PNET) was coined by Hart and Earle in 1973 [1] . These tumours are more common in children. There is considerable confusion and controversy in the classi fication of PNETs [2]. As for the World Health Organization (WHO) classification of brain tumours [3], all undifferentiated (primitive) tumours are derived from common neuroepithelial cells and are therefore classified as PNETs. They have been classified as central PNET (cPNET) or peripheral PNET (pPNET). They differ from each other in natural history, clinicohistological features and spread. However, both have the same poor clinical outcome [4]. To date, 47 cases of PNETs have been reported. Our two cases are exclusive in that both were extradural ones with extension into the thoracic cavity resembling neurofibroma with the exception that both had a very short history of progres-

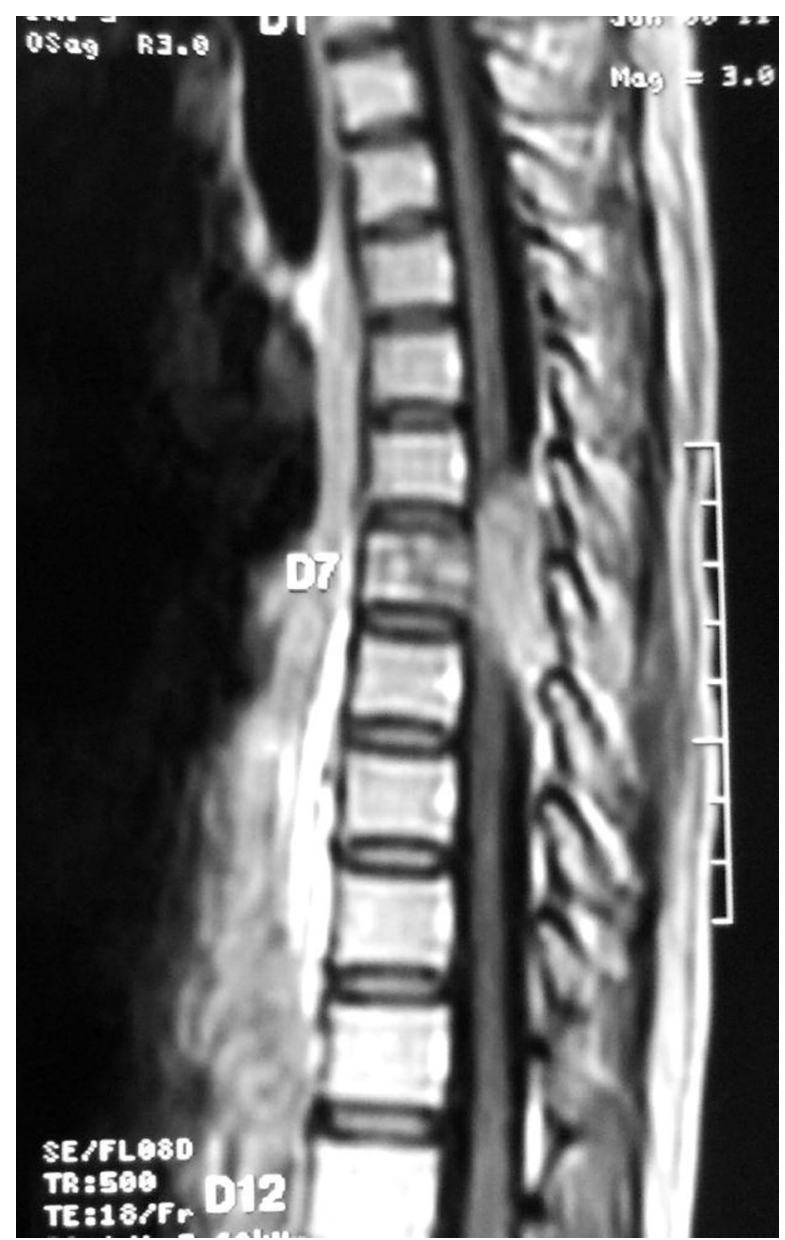

Fig. 1. Case 1: T1-weighted sagittal MR image after contrast injection showing the well-enhanced tumour sion. Few such presentations have been reported previously $[5,6]$.

\section{Case reports}

\section{Case 1}

A 25-year-old woman presented with numbness, tingling and weakness of both feet which started 10 days before admission and progressed upwards, leading to paralysis of both legs for six days and urinary incontinence for one day. On neurological examination, motor power was grade $1 / 5$ in the lower limbs, tendon reflexes were brisk and plantar responses were extensor bilaterally. She had hypoaesthesia below the T7 level. Magnetic resonance imaging (MRI) of the thoracic spine showed an extradural tumour at the T7 level compressing the cord and enhancing well after contrast injection (Figs. 1-3). The lesion extended into the left-side thoracic cavity, giving a picture of neurofibroma. A laminectomy was performed at the T6-T8 level. On exploration, the mass was extradural, soft, reddish-brown, vascular, adherent to the spinal cord and encasing the nerve roots. A total excision was achieved. The thoracic component was removed completely by left posterolateral thoracotomy. Histopathological examination and immunohistochemical staining confirmed the diagnosis of PNET. Postoperative computed tomography (CT) of the head (Fig. 4), thorax and abdomen was negative for any tumour pathology, indicating the primary nature of spinal pathology. By the third postoperative week, the patient was ambulatory with support. She had six cycles of chemotherapy consisting of cyclophosphamide followed by cranio-spinal radiation therapy spread over eight weeks. She was alive at 8-month follow-up postoperatively.

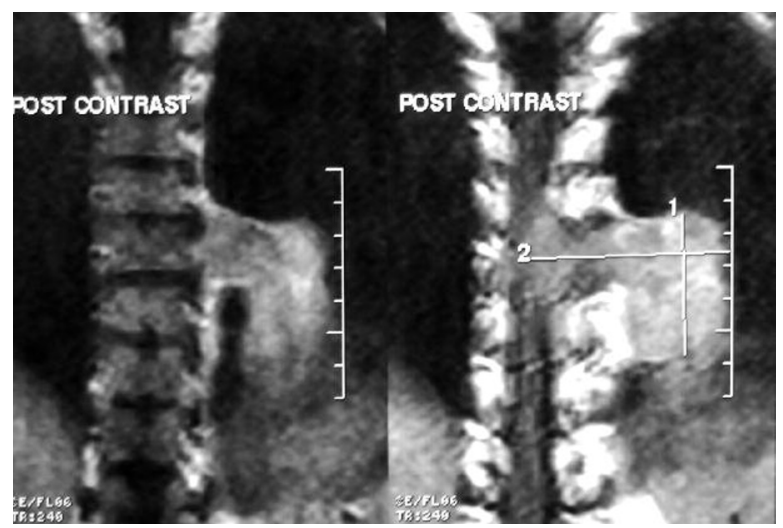

Fig. 2. Case 1: T1-weighted coronal MR image after contrast injection showing extension of the tumour into the left side of the thoracic cavity 

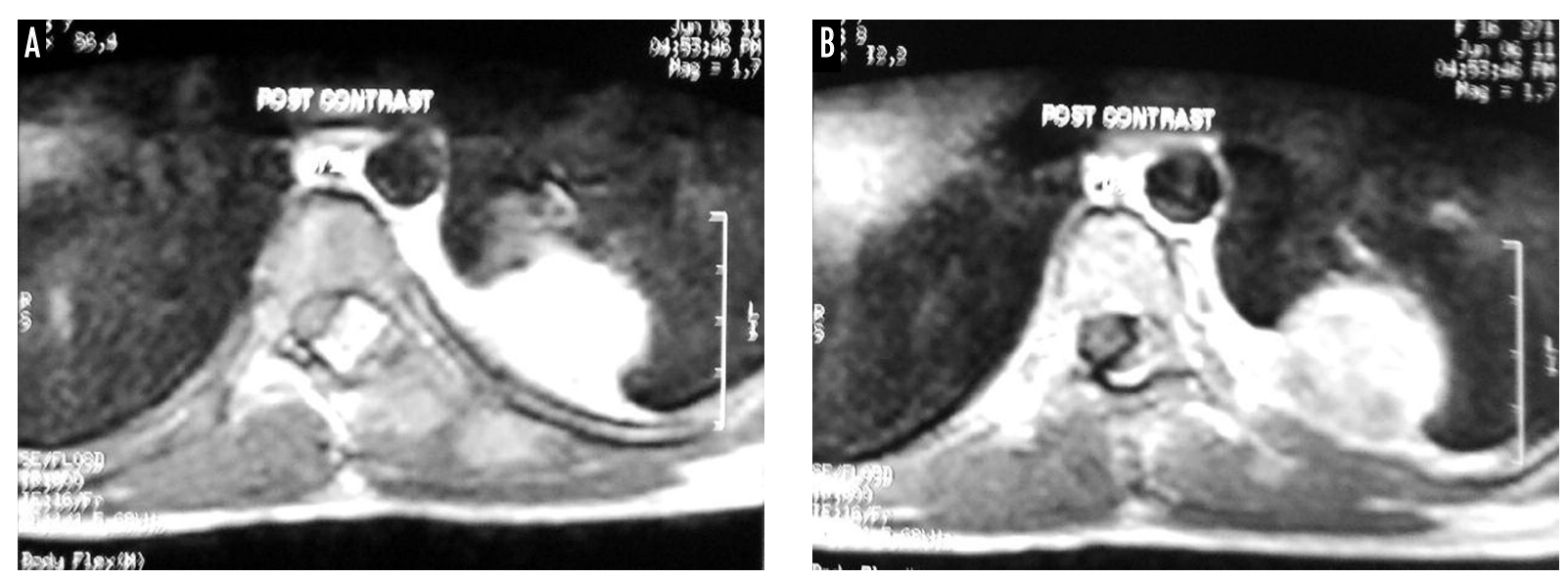

Fig. 3. Case 1: T1-weighted axial MR image after contrast injection showing the tumour compressing the cord to the right and extending through the intervertebral foramen into the left side of the thoracic cavity

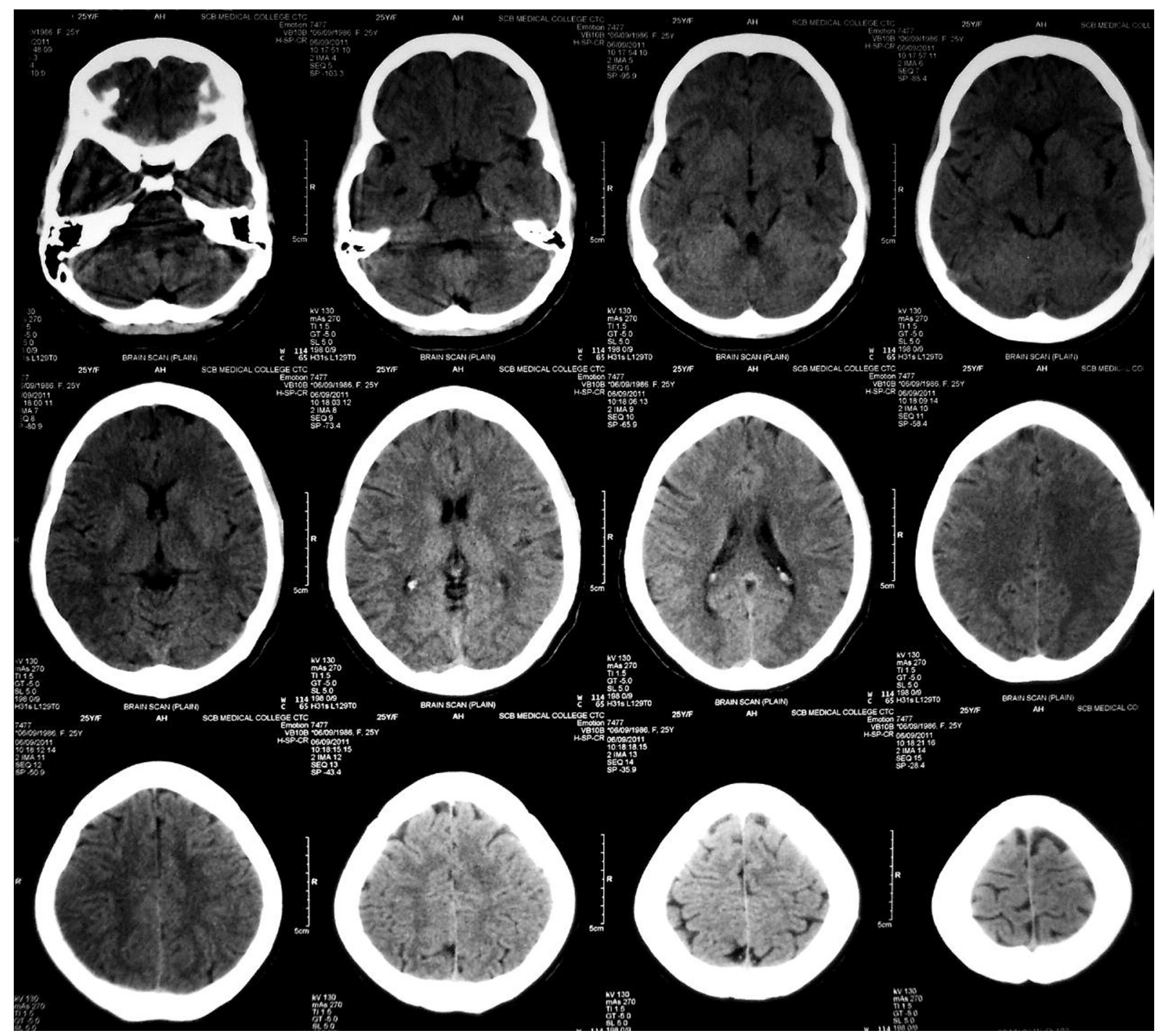

Fig. 4. Case 1: Postoperative cranial computed tomography showing no primary tumour in the brain 


\section{Case 2}

A 36-year-old woman presented with weakness of both lower limbs followed by complete paralysis within a period of 30 days. She was bedridden for seven days before admission. On examination, the motor power was grade $0 / 5$ in both lower limbs. There were signs of myelopathy in lower limbs with exaggerated knee and ankle jerks, ankle clonus, and bilateral Babinski sign. MRI of the cervical spine revealed a lesion extending from T8 to T11. The lesion extended into the left-side thoracic cavity through the dilated intervertebral foramen. The lesion was isointense on T1-weighted image and iso- to hyperintense on T2-weighted image (Figs. 5-7). A provisional diagnosis of spinal neurofibroma was made. A gross total excision of the lesion was achieved with T8-T11 laminectomy. The tumour was soft, friable, highly vascular and completely extradural in location, encasing the nerve root. The thoracic component could be removed partially by left posterolateral thoracotomy. Postoperatively, the patient showed partial improvement in the deficits, with power improving to $2 / 5$. Histo- pathology and immunohistochemistry of the lesion revealed PNET (Figs. 8 and 9). She received focal radiation therapy spread over a period of six weeks, but declined to take chemotherapy. The patient died after 4 months of post-operative follow-up due to distant metastases.

\section{Discussion}

The concept of PNETs has been controversial for more than a decade. In the recently updated WHO classification, PNET is defined as an embryonal tumour composed of undifferentiated or poorly differentiated neuroepithelial cells which have the capacity for or display divergent differentiation along neuronal astrocytic, ependymal, muscular, or melanotic lines. Peripheral PNETs and Ewing's sarcoma (ES) are closely related malignant, small, and round-cell tumours of soft tissue and bones. Both pPNETs and ES strongly express the glycoprotein p30/32 (CD99), which is encoded by the microneme protein 2 (MIC2) gene. Because of immunohistochemical, ultrastructural and molecular bio-

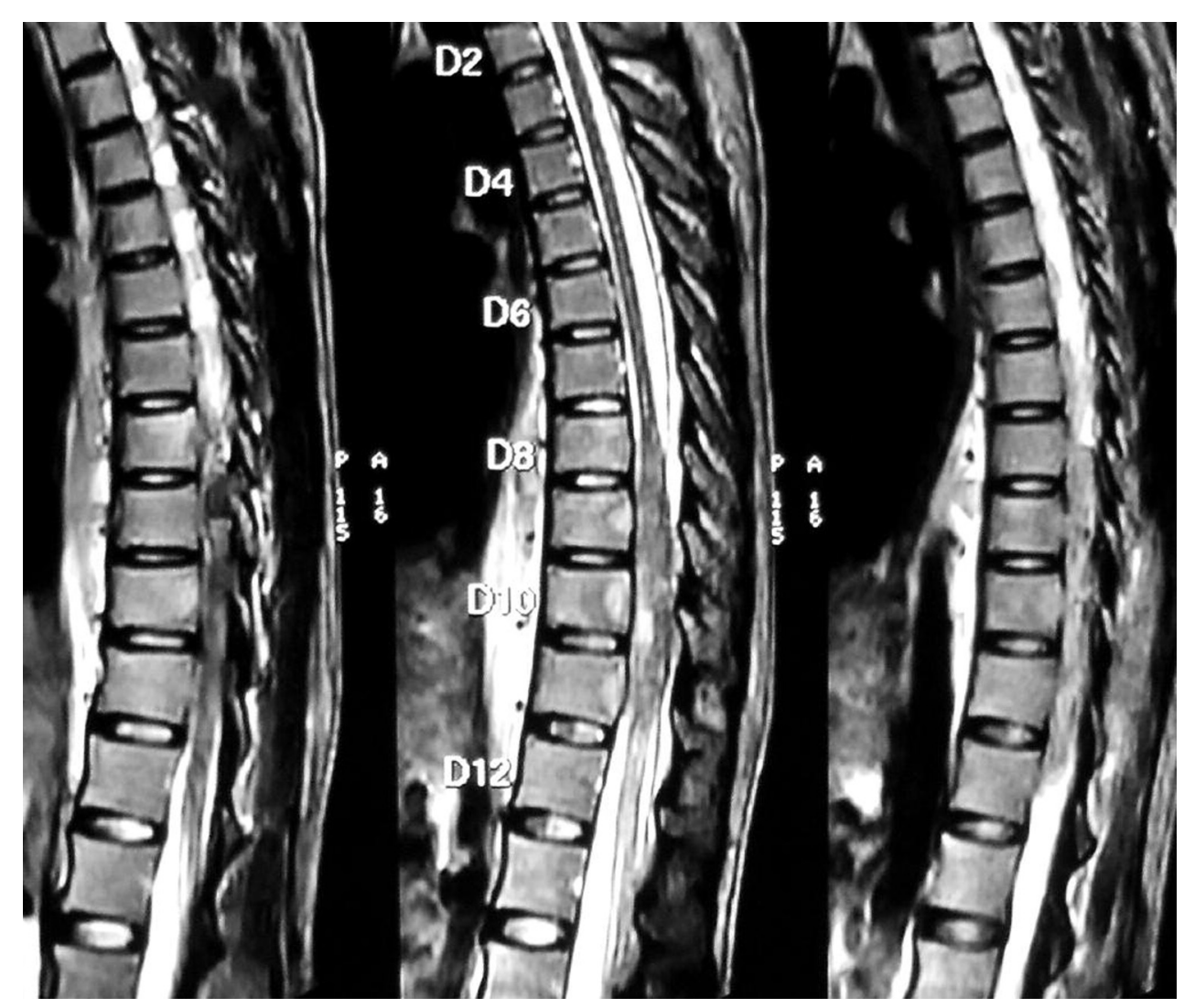

Fig. 5. Case 2: T2-weighted sagittal MR image showing isointense tumour extending from T8 to T11 


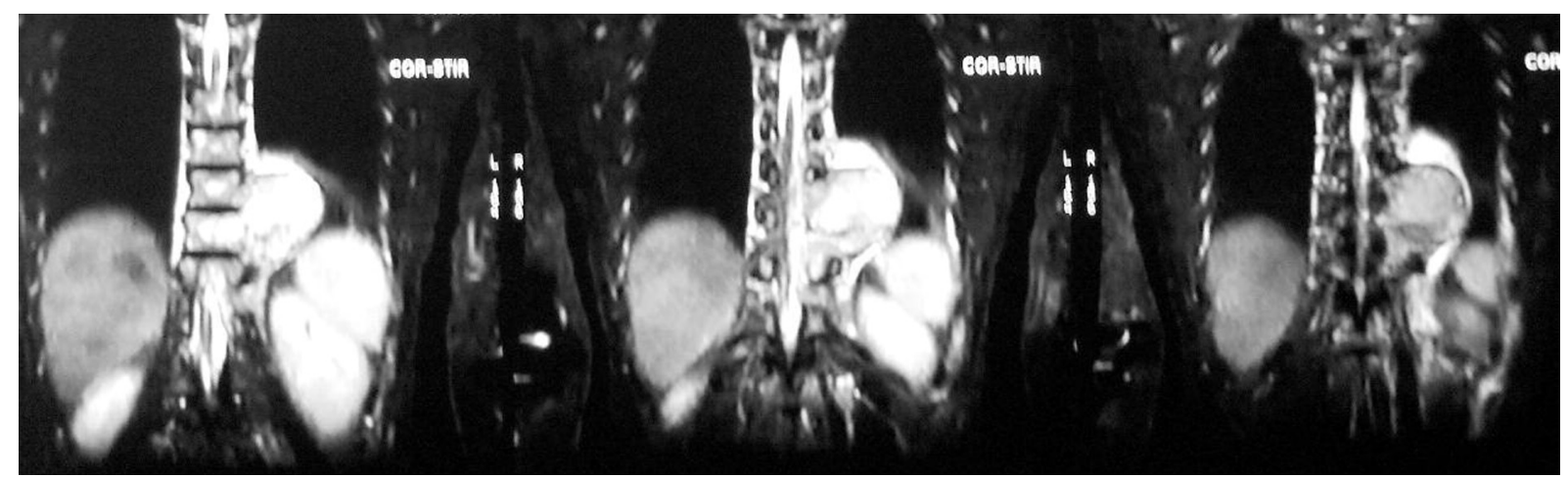

Fig. 6. Case 2: Coronal MR image showing the tumour extension into the left side of the thoracic cavity

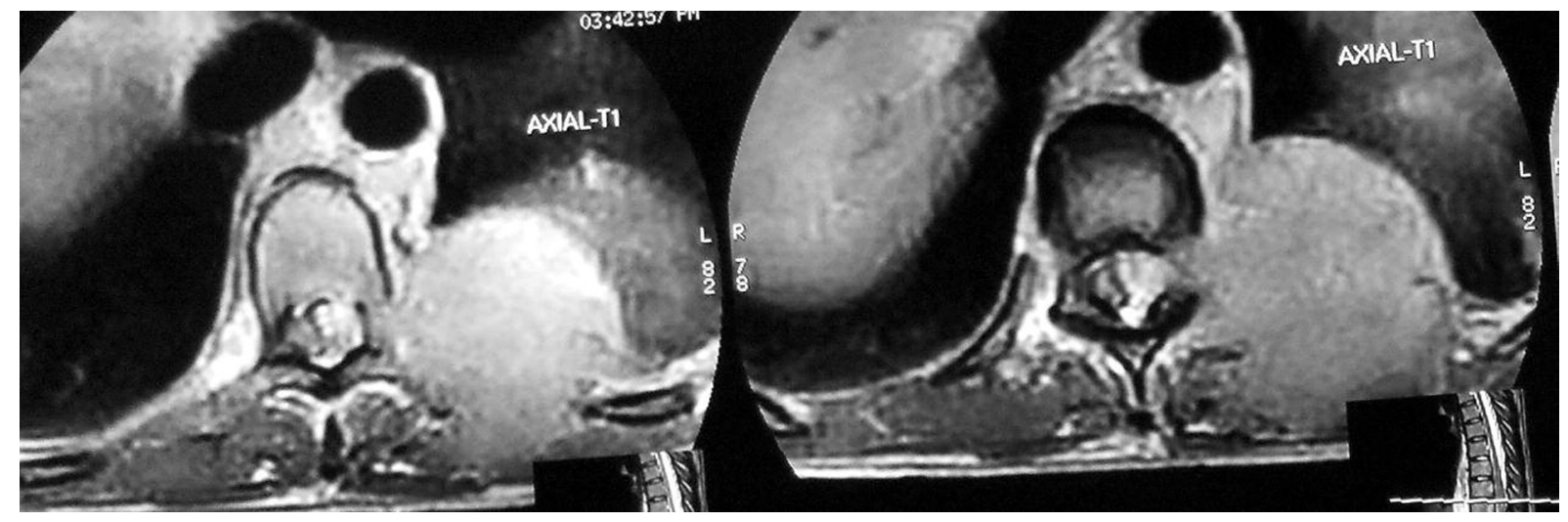

Fig. 7. Case 2: T1-weighted axial MR image showing the tumour

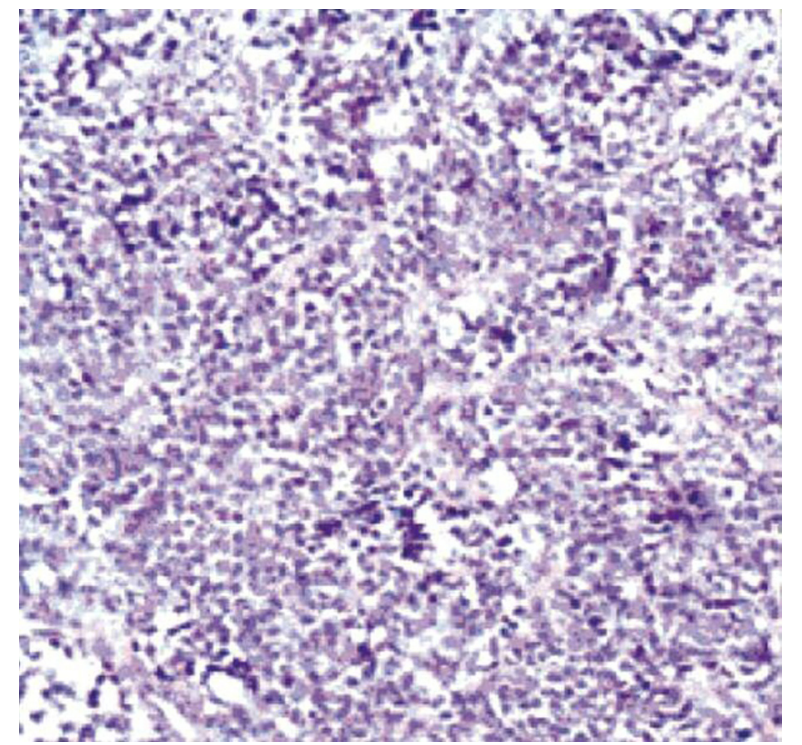

Fig. 8. Case 2: Light microscopy: The tumour cells were small and round morphologically, arranged in groups, with hyperchromatic nuclei and scanty cytoplasm $(H \& E, \times 100)$.

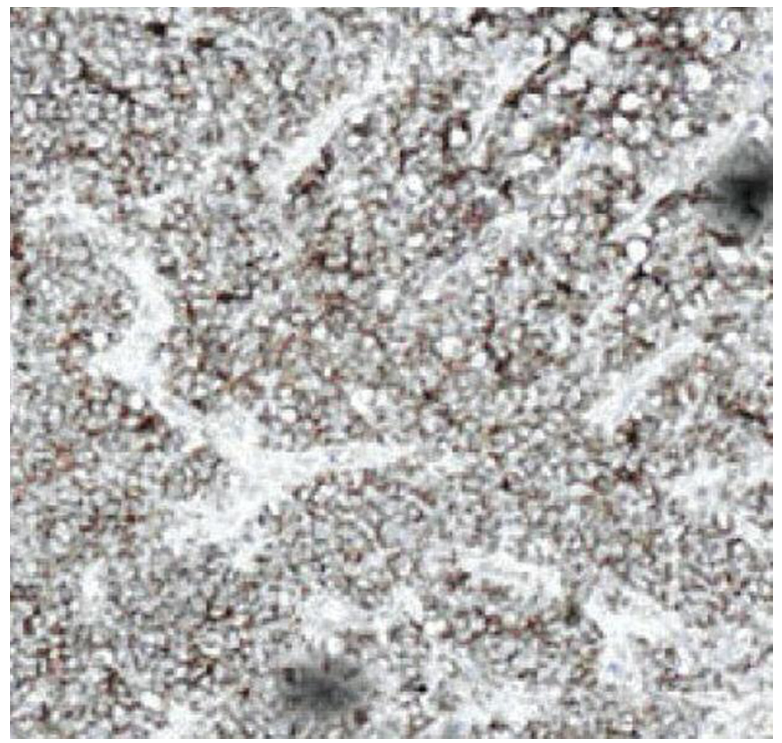

Fig. 9. Case 2: Immunohistochemistry showing $\operatorname{CD} 99(+)$ reactivity 
Table 1. Demographic and clinical data of intraspinal primitive neuroectodermal tumours

\begin{tabular}{|c|c|c|c|c|c|}
\hline $\begin{array}{l}\text { Authors } \\
\text { [Reference] }\end{array}$ & $\begin{array}{c}\text { Age } \\
\text { [years]/sex }\end{array}$ & Level & Location & Metastases & $\begin{array}{l}\text { Survival } \\
\text { [months] }\end{array}$ \\
\hline Smith et al. [13] & $24 / \mathrm{M}$ & Lumbar & Cauda equina & Lung & 10 \\
\hline Kosnik et al. [14] & NA & Cervical & Unknown & None & NA \\
\hline Kosnik et al. [14] & NA & Cervical & Unknown & None & NA \\
\hline Kosnik et al. [14] & NA & Thoraco-lumbar & Unknown & Lung, bone, lymph node & NA \\
\hline Rodriguez et al. [15] & $16 / \mathrm{M}$ & - & - & - & - \\
\hline Kepes et al. [16] & $24 / \mathrm{M}$ & Lumbar & Cauda equina & None & 18 \\
\hline Kepes et al. [16] & $56 / \mathrm{M}$ & Lumbar & Cauda equina & None & Alive at 36 \\
\hline Kepes et al. [16] & $39 / \mathrm{M}$ & Lumbar & Cauda equina & None & 42 \\
\hline Liu et al. [17] & $26 / \mathrm{F}$ & Lumbo-sacral & Extradural & None & Alive at 6 \\
\hline Sevick et al. [18] & $26 / \mathrm{M}$ & Cervical & Intradural and extramedullary & Pleura, bone & 36 \\
\hline Jaksche et al. [19] & $15 / \mathrm{F}$ & Thoraco-lumbar & Intradural and extramedullary & None & 18 \\
\hline Jaksche et al. [19] & $26 / \mathrm{M}$ & Thoraco-lumbar & Intradural and extramedullary & None & 36 \\
\hline Freyer et al. [20] & $7 / \mathrm{F}$ & Thoraco-lumbar & Intramedullary & None & 20 \\
\hline Ogasawara et al. [11] & $16 / \mathrm{M}$ & Lumbar & Intramedullary & Intracranial & 29 \\
\hline McDermott et al. [21] & $47 / \mathrm{M}$ & Lumbar & Cauda equina & None & 16 \\
\hline Kwon et al. [10] & $3 / \mathrm{F}$ & Thoracic & Intramedullary & Intracranial & $<1$ \\
\hline Deme et al. [22] & $22 / \mathrm{F}$ & Thoraco-lumbar & Intramedullary & None & Alive at 15 \\
\hline Koot et al. [23] & $2 / \mathrm{F}$ & Cervical & Extramedullary & None & 12 \\
\hline Papadatos et al. [24] & 23 & Thoracic & Intradural and extramedullary & None & 12 \\
\hline Virani \& Jain $[6]^{*}$ & $4 / \mathrm{M}$ & Thoracic & Extradural & None & Alive at 18 \\
\hline Mawrin et al. [8] & $69 / \mathrm{M}$ & Thoracic & Intramedullary & None & - \\
\hline Yavuz et al. [25] & $18 / \mathrm{F}$ & Lumbar & Extramedullary & None & Alive at 25 \\
\hline Albrecht et al. [26] & $19 / \mathrm{F}$ & Lumbar & Intradural, intramedullary & Local recurrence & 23 \\
\hline Mawrin et al. [8] & $22 / \mathrm{F}$ & Thoracic & Intradural and extramedullary & Local recurrence & Alive at 9 \\
\hline $\begin{array}{l}\text { Izycka-Swieszewska } \\
\text { et al. }[27]\end{array}$ & $26 / \mathrm{M}$ & Cervical & Extraspinal, intrameningeal & Local recurrence & 3 \\
\hline Aydin et al. [28] & $14 / \mathrm{M}$ & Thoracic & Extradural & None & - \\
\hline Kampman et al. [4] & $2 / \mathrm{M}$ & Cervical & Intramedullary & Local recurrence & 7 days \\
\hline Kumar et al. [7] & $9 / \mathrm{F}$ & Thoracic & Extramedullary & None & Alive at 24 \\
\hline Kumar et al. [7] & $8 / \mathrm{M}$ & Cervical & Extradural & Local recurrence & Recurred at 6 \\
\hline Kumar et al. [7] & $18 / \mathrm{M}$ & Holocord & Intramedullary & None & Alive at 6 weeks \\
\hline Nutman et al. [29] & $19 / \mathrm{F}$ & Thoraco-lumbar & Intradural and extramedullary & None & Alive at 24 \\
\hline Musahl et al. [30] & $27 / \mathrm{M}$ & Sacral & Extradural & - & Alive at 24 \\
\hline Dorfmüller et al. [31] & $32 / \mathrm{M}$ & Sacral & - & Local recurrence & Alive at 29 \\
\hline Dorfmüller et al. [31]* & $17 / \mathrm{M}$ & Lumbar & Extradural and paraspinal & Hemispheres & Alive at 23 \\
\hline Isotalo et al. [32] & $52 / \mathrm{M}$ & Lumbo-sacral & Intradural & None & Alive at 12 \\
\hline Albrecht et al. [26] & $29 / \mathrm{F}$ & Thoracic & Intradural & Local recurrence & Alive at 17 \\
\hline
\end{tabular}


Table 1. Cont

\begin{tabular}{|c|c|c|c|c|c|}
\hline $\begin{array}{l}\text { Authors } \\
\text { [Reference] }\end{array}$ & $\begin{array}{c}\text { Age } \\
\text { [years]/sex }\end{array}$ & Level & Location & Metastases & $\begin{array}{c}\text { Survival } \\
\text { [months] }\end{array}$ \\
\hline Akyüz et al. [9] & $31 / \mathrm{M}$ & Lumbar & Intradural and extramedullary & Local recurrence & Alive at 24 \\
\hline Weber et al. [33] & $26 / \mathrm{M}$ & Lumbar & - & Local recurrence & - \\
\hline Kimet al. [34] & $17 / \mathrm{M}$ & Thoraco-lumbar & Intramedullary & None & Alive at 24 \\
\hline Perry et al. [35] & $27 / \mathrm{M}$ & Lumbar & Extradural & None & - \\
\hline Perry et al. [35] & $16 / \mathrm{F}$ & Lumbar & Extradural & None & Alive at 5 \\
\hline Jingyu et al. [36] & $19 / \mathrm{F}$ & Cervical & Intradural and extramedullary & None & Alive at 10 \\
\hline Jingyu et al. [36] & $46 / \mathrm{M}$ & Thoracic & Intradural and extramedullary & None & Alive at 14 \\
\hline Jingyu et al. [36] & $58 / \mathrm{M}$ & Thoracic & Extradural & Vertebrae & Alive at 25 \\
\hline Jingyu et al. [36] & $14 / \mathrm{M}$ & Thoracic & Intradural and extramedullary & None & Alive at 6 \\
\hline Gurkanlar et al. [37] & 40 days/M & Thoraco-lumbar & Intradural and extramedullary & None & 6 \\
\hline Nayak et al. [5]* & $18 / \mathrm{F}$ & Thoracic & Extradural and paraspinal & - & - \\
\hline Case $1 *$ presented here & $25 / \mathrm{F}$ & Thoracic & Extradural and paraspinal & None & Alive at 8 \\
\hline Case $2 *$ presented here & $36 / \mathrm{F}$ & Thoracic & Extradural and paraspinal & Lung & 4 \\
\hline
\end{tabular}

* Primary intraspinal primitive neuroectodermal tumour cases presenting with paraspinal mass

$F$-female; $M$ - male; $N A$ - not available

logical similarities, pPNETs and ES have recently been categorized into the Ewing family of tumours $[7,8]$.

These tumours commonly occur in the cerebellum but can arise in the pineal gland, cerebrum, spinal cord, brain stem, and peripheral nerves. Primary spinal PNETs come under the group of pPNET and most cases involving the spinal cord are drop metastases from primary intracranial tumours by cerebrospinal fluid. Intracranial seeding has also been reported in the literature [9-11]. Primary intraspinal PNETs are rare but so far 47 cases have been well described in the literature. We have summarized the clinical characteristics of the 49 cases, including our two cases, of intraspinal PNET reported to date (Table 1). However, the occurrence of exclusive extradural intraspinal PNET mimicking neurofibroma due to its intrathoracic component is extremely rare and five such cases (marked with asterisks in Table 1) have been reported thus far including our two cases.

Spinal PNET is characterized by adult onset and male predominance. The average age at presentation for patients with intraspinal PNET is much higher than the average age for intracranial PNET [12]. The duration of illness is often short, less than four months, and it can be as short as 10 days, as seen in one of our patients (Case 1). These tumours can occur at any level of the spine and the location can be intramedullary, intradural-extramedullary or extradural. Primary intraspinal PNETs show positive immunostaining for CD99 due to their biological similarity with Ewing's sarcoma group of tumours and they are included under the term pPNET. Both our cases were positive for CD99.

Cranial symptoms are not a feature of primary intraspinal PNET. This is a feature that distinguishes primary intraspinal PNET from primary intracranial PNET with spinal metastasis.

The prognosis of these tumours is very poor and treatment is far from satisfactory. Radical resection combined with radiation therapy and chemotherapy is the preferred treatment and leads to better outcomes. One of our patients, who is still alive 8 months postoperatively, underwent radical excision of both spinal and thoracic components with both radio- and chemotherapy. The other patient, who died 4 months postoperatively, had partial excision of the thoracic component due to adhesion to thoracic vascular structures and declined to undergo chemotherapy. This emphasizes the role of both radical resection along with adjuvant therapy in extending as well as improving the quality of life after surgery. Adjunctive immunotherapy is currently being investigated as a possible therapy [6]. The causes of death include metastatic disease, aggressive local spread, and progressive spinal cord involvement. 
Primary spinal PNETs are now more frequently diagnosed as a result of improved histological techniques including immunohistochemistry. Previously, these cases were diagnosed as astrocytoma, ependymoma, or neurofibroma, depending on the location of the tumour in relation to the dura. Both our cases were strongly suspected as cases of neurofibroma due to their well-defined dumb-bell extension coming out into the thoracic cavity through the intervertebral foramina. Neurofibromas have a good prognosis, once they are fully excised. On the other hand, the PNETs present with a short history of symptoms in comparison to neurofibromas, as evidenced in both our cases. They tend to infiltrate into surrounding tissues and erode the dura. However, these findings were absent in our cases.

\section{Conclusions}

Our cases illustrate the adult age distribution and clinico-radiological features suggesting neurofibroma as the first diagnosis. However, the final diagnosis based on intraoperative finding and histological features was primary intraspinal PNET. Only three such cases of spinal PNET resembling neurofibroma have been reported in the literature. This is an excellent illustration of presentation of these rare tumours; they should be considered in differential diagnosis of short duration paraparesis.

These tumours are rarely diagnosed preoperatively with certainty, based on clinico-radiological features only. Good histological diagnosis supported with immunohistochemistry should be done in every suspected case so as to diagnose these relatively rare tumours. Due to their poor prognosis in spite of good surgical excision combined with aggressive adjuvant therapy, studies on molecular pathogenesis of these tumours and their application through immunotherapy are the key to future advances in treatment, which are currently lacking.

\section{Disclosure}

Authors report no conflict of interest.

\section{References}

1. Hart M.N., Earle K.M. Primitive neuroectodermal tumors of the brain in children. Cancer 1973; 32: 890-897.

2. Nishio S., Morioka T., Fukui M. Primitive neuroectodermal tumors. Crit Rev Neurosurg 1998; 8: 261-268.

3. Brat D.J., Parisi J.E., Kleinschmidt-DeMasters B.K., et al. Surgical neuropathology update: A review of changes introduced by the WHO classification of tumours of the central nervous system, $4^{\text {th }}$ ed. Arch Pathol Lab Med 2008; 132: 993-1007.

4. Kampman W.A., Kros J.M., De Jong T.H., et al. Primitive neuroectodermal tumours (PNETs) located in the spinal canal; the relevance of classification as central or peripheral PNET: Case report of a primary spinal PNET occurrence with a critical literature review. J Neurooncol 2006; 77: 65-72.

5. Nayak P.K., Rao K.M., Sahoo G.C., et al. Primary thoracic primitive neuroectodermal tumor mimicking as neurofibroma. Neurol India 2011; 59: 648-649.

6. Virani M.J., Jain S. Primary Intraspinal primitive neuroectodermal tumor (PNET): a rare occurrence. Neurol India 2002; 50: 75-80.

7. Kumar R., Reddy S.J., Wani A.A., et al. Primary spinal primitive neuroectodermal tumor: case series and review of the literature. Pediatr Neurosurg 2007; 43: 1-6.

8. Mawrin C., Synowitz H.J., Kirches E., et al. Primary primitive neuroectodermal tumor of the spinal cord: case report and review of the literature. Clin Neurol Neurosurg 2002; 104: 36-40.

9. Akyüz M., Demiral A.N., Gürer I.E., et al. Primary primitive neuro-ectodermal tumor of cauda equina with intracranial seeding. Acta Neurochir (Wien) 2004; 146: 525-528.

10. Kwon O.K., Wang K.C., Kim C.J., et al. Primary intramedullary spinal cord primitive neuroectodermal tumor with intracranial seeding in an infant. Childs Nerv Syst 1996; 12: 633-636.

11. Ogasawara H., Kiya K., Kurisu K., et al. Intracranial metastasis from a spinal cord primitive neuroectodermal tumor: case report. Surg Neurol 1992; 37: 307-312.

12. Hargrave D.R., Zacharoulis S. Pediatric CNS tumors: current treatment and future directions. Expert Rev Neurother 2007; 7: 1029-1042.

13. Smith D.R., Hardman J.M., Earle K.M. Metastasizing neuroectodermal tumors of the central nervous system. $J$ Neurosurg 1969; 31: 50-58.

14. Kosnik E.J., Boesel C.P., Bay J., et al. Primitive neuroectodermal tumors of the central nervous system in children. $J$ Neurosurg 1978; 48: 741-746.

15. Rodriguez M., Dinapoli R.P. Spinal cord compression: with special reference to metastatic epidural tumors. Mayo Clin Proc 1980; 55: 442-448.

16. Kepes J.J., Belton K., Roessmann U., et al. Primitive neuroectodermal tumors of the cauda equina in adults with no detectable primary intracranial neoplasm-three case studies. Clin Neuropathol 1985; 4: 1-11.

17. Liu H.M., Yang W.C., Garcia R.L., et al. Intraspinal primitive neuroectodermal tumor arising from the sacral spinal nerve root. J Comput Tomogr 1987; 11: 350-354.

18. Sevick R.J., Johns R.D., Curry B.J. Primary spinal primitive neuroectodermal tumor with extraneural metastases. AJNR Am J Neuroradiol 1987; 8: 1151-1152.

19. Jaksche H., Wöckel W., Wernert N. Primary spinal medulloblastomas? Neurosurg Rev 1988; 11: 259-265.

20. Freyer D.R., Hutchinson R.J., McKeever P.E. Primary primitive neuroectodermal tumor of the spinal cord associated with neural tube defect. Pediatr Neurosci 1989; 15: 181-187.

21. McDermott V.G., el-Jabbour J.N., Sellar R.J., et al. Primitive neuroectodermal tumour of the cauda equina. Neuroradiology 1994; 36: 228-230. 
22. Deme S., Ang L.C., Skaf G., et al. Primary intramedullary primitive neuroectodermal tumor of the spinal cord: case report and review of the literature. Neurosurgery 1997; 41: 1417-1420.

23. Koot R.W., Henneveld H.T., Albrecht K.W. Two children with unusual causes of torticollis: Primitive neuroectodermal tumor and Grisel's syndrome. Ned Tijdschr Geneeskd 1998; 142: 1030-1033.

24. Papadatos D., Albrecht S., Mohr G., et al. Exophytic primitive neuroectodermal tumor of the spinal cord. Am J Neuroradiol 1998; 19: 787-789.

25. Yavuz A.A., Yaris N., Yavuz M.N., et al. Primary intraspinal primitive neuroectodermal tumor: Case report of a tumor arising from the sacral spinal nerve root and review of the literature. $A m$ J Clin Oncol 2002; 25: 135-139.

26. Albrecht C.F., Weiss E., Schulz-Schaeffer W.J., et al. Primary intraspinal primitive neuroectodermal tumor: Report of two cases and review of the literature. J Neurooncol 2003; 61: 113-120.

27. Izycka-Swieszewska E., Debiec-Rychter M., Wasag B., et al. A unique occurrence of a cerebral atypical teratoid/rhabdoid tumor in an infant and a spinal canal primitive neuroectodermal tumor in her father. $J$ Neurooncol 2003; 61: 219-225.

28. Aydin M.V., Sen O., Ozel S., et al. Primary primitive neuroectodermal tumor within the spinal epidural space: report of a case and review of the literature. Neurol Res 2004; 26: 774-777.

29. Nutman A., Postovsky S., Zaidman I., et al. Primary intraspinal primitive neuroectodermal tumor treated with autologous stem cell transplantation: case report and review of the literature. Pediatr Hematol Oncol 2007; 24: 53-61.

30. Musahl V., Rihn J.A., Fumich F.E., et al. Sacral intraspinal extradural primitive neuroectodermal tumor: A case report. Spine J 2008; 8: 1024-1029.

31. Dorfmüller G., Würtz F.G., Umschaden H.W., et al. Intraspinal primitive neuroectodermal tumour: Report of two cases and review of the literature. Acta Neurochir (Wien) 1999; 141: 1169-1175.

32. Isotalo P.A., Agbi C., Davidson B., et al. Primary primitive neuroectodermal tumor of the cauda equina. Hum Pathol 2000; 31: 999-1001.

33. Weber D.C., Rutz H.P., Lomax A.J., et al. First spinal axis segment irradiation with spot-scanning proton beam delivered in the treatment of a lumbar primitive neuroectodermal tumour. Case report and review of the literature. Clin Oncol (R Coll Radiol) 2004; 16: 326-331.

34. Kim Y.W., Jin B.H., Kim T.S., et al. Primary intraspinal primitive neuroectodermal tumor at conus medullaris. Yonsei Med J 2004; 45: 533-538.

35. Perry R., Gonzales I., Finlay J., et al. Primary peripheral primitive neuroectodermal tumors of the spinal cord: report of two cases and review of the literature. J Neurooncol 2007; 81: 259-264.

36. Jingyu C., Jinning S., Hui M., et al. Intraspinal primitive neu roectodermal tumors: report of four cases and review of the literature. Neurol India 2009; 57: 661-668.

37. Gurkanlar D., Korkmaz E., Gurler I.E., et al. Multilevel primary intraspinal PNETs in an infant associated with hydrocephalus. Turk Neurosurg 2010; 20: 82-85. 